\title{
Doha Round Baggage: Implications for Economic Reforms in Pakistan and other Southern Countries
}

\author{
Naheed Zia Khan"
}

\section{Abstract}

This study is based on the premise that agriculture remains the key issue in all reform efforts of Pakistan and the Doha Round of trade talks has strategic significance for the second round of the country's farm sector reforms. It is argued that although there are differences among the individual developing countries, the majority have a comparative advantage in agricultural production and removing farm sector export subsidies and tradedistorting, domestic subsidies is their common concern. Evidence is provided to support the view that the Uruguay Round negotiations on agricultural subsidies are not a done deal, because although signed by the members, the Agreement on Agriculture is not 'ratified' by the recent farm bills of the developed countries which continue to defy economic logic and the WTO (World Trade Organization). On the other hand, the evidence provided from Pakistan shows that the governments of developing countries are not fighting the farmers' cause since they are poorly managing agricultural policy and have been overly compliant with respect to the Uruguay Round ruling on reducing farm subsidies and increasing trade liberalization. The analysis shows that although the developed countries stand to gain far more from the liberalization of trade in agricultural commodities than the developing countries, the handful of farmers in developed countries are the stumbling block to the regeneration of world trade. It is argued that to alleviate world poverty, the developed countries need to demonstrate their willingness to gradually remove both the absolute value of subsidies provided to their farmers and the tariff and non-tariff barriers that protect agriculture. Finally, the author maintains that at world trade forums, the developing countries have exhibited poor representation due to lack of leadership.

\section{Introduction}

The external sector is a fundamental policy concern of both the first and second generation economic reforms in Pakistan. In an economic

\footnotetext{
* Professor of Economics, Fatima Jinnah Women University, Rawalpindi.
} 
world dominated by trade, the rules of the World Trade Organization (WTO) prevail. These rules are the outcome of the Uruguay Round (UR) of trade talks. The UR began in 1986 and culminated in converting the 'interim' Secretariat of the General Agreement on Tariffs and Trade (GATT) into the WTO. The UR was the eighth round of GATT and it included agriculture and services in the trade talks for the first time. ${ }^{1}$ With 150 member countries in January 2007, the WTO enforces the 1993 UR agreement; the Agreement on Agriculture (AoA), the General Agreement on Trade in Services (GATS), the agreement on Trade Related Intellectual Property Rights (TRIPs) and Trade Related Investment Measures (TRIMs). The members are required to abide by the WTO rules which are prolific, running into thousands of pages. Following an aborted attempt in Seattle in late 1999, the Ministerial Meeting of the WTO in Doha, the capital city of Qatar, launched the next comprehensive round of multilateral trade negotiations in November 2001. The Doha Round aims at reducing tariffs, subsidies and other barriers to global commerce in order to boost progress, apparently, in the underdeveloped parts of the world. Like its predecessor, the UR, agricultural subsidies remain the sticking point also in the Doha Round of trade talks, causing the suspension of the process in July 2006, as the multilateral negotiation on this thorny issue failed to reach agreement even after a five-year effort.

There is a broad range of issues that are of important concern for economic reforms in developing countries such as Pakistan. One key issue relates to the extent to which they have so far benefited from the UR reforms, most notably the commitments to liberalize trade in agriculture. In the wake of the break down of the trade talks in July 2006, this study takes a hard look at developments in agricultural policies since the UR agreement. The analysis is divided into four parts. Part 1 discusses the importance of agriculture in Pakistan's economy relative to the economies of selected Asian and African countries. Part II presents the estimates, found in the literature, of the welfare gains from removing trade barriers globally. Pakistan's performance in reforming its agricultural sector is also discussed in this part. Part III analyzes the size and significance of the developed countries' farm subsidies in the Post-UR agreement period. Finally, before presenting the conclusion of this study, Part IV discusses the factors relating to agricultural subsidies hindering the reform efforts in developing countries.

${ }^{1}$ The earlier Rounds were Geneva 1947; Annecy 1948; Torquay 1950; Geneva 1956; Dillon 1960-61; Kennedy 1964-67; and Tokyo 1973-79. 


\section{Part I}

During the first reform period, Pakistan's economic performance compared favorably with most of its Asian counterparts. This is supported by the last century's scenario presented in Table-1. The figures listed in Tables-1 show that Pakistan fared well in comparison against the averages of low income/ middle income countries and the world, and also with the individual countries included in the list. However, many of its counterparts, both in Asia and Africa, are much ahead on the literacy front where Pakistan lags behind even the low income countries and markedly behind the middle income countries.

Table-1: Economic and Social Indicators of Selected Developing Countries (Asia and Africa)

\begin{tabular}{|c|c|c|c|c|}
\hline \multirow[t]{2}{*}{ Category } & \multicolumn{2}{|c|}{$\begin{array}{c}\text { National Income } \\
\text { (growth rate) } \\
1965-99 \text { (\% per annum) }\end{array}$} & \multicolumn{2}{|c|}{$\begin{array}{c}\text { Social Indicators } \\
1999\end{array}$} \\
\hline & GDP & $\begin{array}{c}\text { GDP } \\
\text { Per Capita }\end{array}$ & $\begin{array}{c}\begin{array}{c}\text { Life Expectancy } \\
\text { (years) }\end{array} \\
\end{array}$ & $\begin{array}{c}\text { Adult Illiteracy } \\
\text { Rate (\%) }\end{array}$ \\
\hline \multicolumn{5}{|l|}{ 1. Country } \\
\hline Bangladesh & 3.8 & 1.3 & 61 & 59 \\
\hline Egypt & 5.6 & 3.3 & 67 & 45 \\
\hline Kenya & 4.7 & 1.2 & 48 & 29 \\
\hline India & 4.6 & 2.4 & 63 & 44 \\
\hline Indonesia & 6.9 & 4.8 & 66 & 5 \\
\hline Iran & 1.7 & -1.0 & 71 & 24 \\
\hline Malaysia & 7.0 & 4.3 & 72 & 13 \\
\hline Mauritius & 5.2 & 3.9 & 71 & 16 \\
\hline Oman & 9.5 & 5.0 & 73 & 30 \\
\hline Pakistan & 5.6 & 2.7 & 63 & 55 \\
\hline Singapore & 8.3 & 6.3 & 78 & 8 \\
\hline South Africa & 2.3 & 0.0 & 48 & 15 \\
\hline Sri Lanka & 4.6 & 3.0 & 73 & 9 \\
\hline Thailand & 7.3 & 5.1 & 69 & 5 \\
\hline \multicolumn{5}{|c|}{ 2. Country Group } \\
\hline Low Income & 4.1 & 1.8 & 59 & 39 \\
\hline Middle Income & 4.2 & 2.4 & 70 & 15 \\
\hline 3. World & 3.3 & 1.6 & 66 & n.a. \\
\hline
\end{tabular}

Source: World Bank (2001a). 
Pakistan's economic performance is mainly dependent on the performance of its agricultural sector, the lifeline of the country. Table-2 presents the contribution of Pakistan's agricultural sector in its economy relative to the developing countries included in the comparisons listed in Table-1. All countries included in the list had overwhelmingly agrarian economic structures about two generations ago. However, the drive for modernization and industrialization which began in the later half of the $20^{\text {th }}$ century has varyingly affected different countries. The indicators listed in Table-2 show the relative importance of agriculture in the countries' economies during the part of the first reform period of the $20^{\text {th }}$ century.

Table-2: Agriculture's Contribution to the Internal and External Sectors of the Economy

(Selected Developing Countries of Asia and Africa)

\begin{tabular}{|c|c|c|c|c|c|c|c|}
\hline \multirow[t]{3}{*}{ Country } & \multirow{2}{*}{\multicolumn{3}{|c|}{$\begin{array}{l}\text { Agricultural internal } \\
\text { sector shares and } \\
\text { growth rate (\%) }\end{array}$}} & \multirow{3}{*}{$\begin{array}{c}\text { Grain } \\
\text { self- } \\
\text { sufficiency } \\
(\%) \\
1995-99\end{array}$} & \multicolumn{3}{|c|}{$\begin{array}{c}\text { Agricultural external sector } \\
\text { indicators }\end{array}$} \\
\hline & & & & & \multirow{2}{*}{$\begin{array}{c}\text { Merchandise } \\
\text { exports } \\
\text { (\% share) } \\
1995-99\end{array}$} & \multicolumn{2}{|c|}{ Indices (1995-99) } \\
\hline & $\begin{array}{l}\begin{array}{c}\text { Labor } \\
\text { force } \\
1990\end{array} \\
\end{array}$ & $\begin{array}{l}\text { GDP } \\
1999\end{array}$ & $\begin{array}{l}\text { Growth } \\
\text { rate } \\
1965-99\end{array}$ & & & $\begin{array}{l}\text { Comparative } \\
\text { advantage } \\
\text { index }\end{array}$ & $\begin{array}{c}\text { Net } \\
\text { export } \\
\text { index }\end{array}$ \\
\hline Bangladesh & 66 & 25 & 2.1 & 88 & 11 & 1.07 & -0.49 \\
\hline Egypt & 39 & 17 & 2.8 & 110 & 15 & 1.45 & -0.78 \\
\hline Kenya & 19 & 23 & 3.4 & 85 & 64 & 6.06 & 0.46 \\
\hline India & 69 & 28 & 2.8 & 99 & 20 & 1.88 & 0.28 \\
\hline Indonesia & 56 & 19 & 3.8 & 89 & 17 & 1.56 & 0.20 \\
\hline Iran & 26 & 21 & 4.5 & 130 & 6 & 0.70 & -0.49 \\
\hline Malaysia & 26 & 11 & 2.9 & 27 & 13 & 1.26 & 0.36 \\
\hline Mauritius & 16 & 6 & 0.3 & 0 & 28 & 2.63 & 0.08 \\
\hline Oman & 45 & 3 & n.a. & n.a. & 5 & 0.44 & -0.50 \\
\hline Pakistan & 51 & 27 & 4.1 & 101 & 72 & 1.39 & -0.33 \\
\hline Singapore & 1 & 0.2 & -1.5 & 0.00 & 4 & -1.00 & -1.00 \\
\hline South Africa & 14 & 4 & 2.0 & 146 & 14 & 1.33 & 0.27 \\
\hline Sri Lanka & 48 & 21 & 2.7 & 59 & 23 & 2.18 & 0.40 \\
\hline Thailand & 64 & 11 & 3.9 & 142 & 23 & 2.15 & 0.45 \\
\hline
\end{tabular}

Source: World Bank (2001a) and FAO (2001).

- Agriculture's share of the country's exports relative to its share of global merchandise exports.

- Agricultural exports minus imports as a ratio of agricultural exports plus imports. 
The comparisons show that during the first reform period agriculture played a very important role in Pakistan's economy, both in the internal and external sectors. Two of the three components of internal balance are full employment and economic growth. It is normal for agriculture's contribution to production and employment to decline in relative importance as an economy grows. However, the process is slow in labor abundant countries such as Pakistan, starting from a low industrial base and facing the acute shortage of both human and physical capital. Table-2 suggests that for the upkeep of the internal balance of Pakistan's economy, agriculture appears to remain the most important sector also during the second reform period; more than half of the country's labor force is still engaged in agriculture and the sector's contribution to Gross Domestic Product (GDP) is well above a quarter of the total. ${ }^{2}$ Thus, agriculture remains the major source of Pakistan's economic growth. More importantly, the agricultural sector is also to be credited with achieving the strategic target of grain self-sufficiency which must be maintained in the future, as it is one of the prerequisites for sustainable development.

Although the history of Pakistan's external balance happens to be a sorry affair, agriculture has always provided it a saving grace through the farm sector's huge direct and indirect contribution to the country's merchandise export earnings. ${ }^{3}$ During the first reform period, a low comparative advantage index of Pakistan in agriculture, relative to Thailand, Sri Lanka and Kenya, must be adjusted for the huge share of its textiles sector in export earnings which largely depends on the raw cotton produced in the country. ${ }^{4}$ Another index, registered in the final column of Table-2, accounts for the imports of agricultural products. It ranges between -1 and +1 , for net importers and exporters respectively. The sign and the size of Pakistan's index, -0.33 , indicates that during the first reform period the country has been fairly open in the domestic market to competition from the rest of the world. The same cannot be maintained for Iran and Oman whose economies are largely dependent on the

\footnotetext{
${ }^{2}$ The agricultural share of labor force declined to 48.42 percent in 2002 (see, Pakistan Economic Survey, 2002-03, Statistical Appendix, Table 12.11, p. 121).

${ }^{3}$ The indirect contribution of agriculture to export earnings comes from the textile sector which contributed about 60 percent of the export earnings during 1978-94. Pakistan is the fifth largest cotton producer in the world and most of its textile export earnings depend on the raw cotton produced in the country (see Khan, 1998).

${ }^{4}$ The agricultural competitiveness listed in Table 2 is based on the computation of Balassa's index of 'revealed' comparative advantage, which is agriculture's share of a country's export relative to agriculture's share of global exports. The ratios necessarily have a global average of unity (see Balassa, 1965).
} 
earnings from oil exports, while both Egypt and Singapore are now considered overwhelmingly service economies.

\section{Part II}

Since 1945, multilateral trade has been a greater engine for prosperity than any other form of international economic cooperation. However, tensions in the world trading system began to arise in the early 1970s. A first attempt to shore up the system came with the Tokyo Round of GATT talks which continued from 1973 to 1979. As mentioned earlier, the UR was launched in 1986. It had 116 participants and it was originally supposed to end in 1990 but did not, and lasted for eight years. The UR began on a note of optimism with the exercise of opening markets including the markets for agricultural commodities. However, seven years later in 1993, the issue of the developed countries' huge farm subsidies brought the UR close to desperation. After a protracted feud between the European Union (EU) and the United States (US), the UR ended successfully in the formal signing of the trade agreements in April 1994. The UR agreement was heralded as a watershed in the history of world trade and was expected to lead to huge welfare gains around the world. Table-3 lists the welfare gains, computed both for the developed and the developing countries, from removing trade barriers globally, in the postUR world of 2005 .

It is interesting to note in Table-3 that not only are the welfare gains for the developed countries the largest in freeing international trade in agriculture and food, it is the only sector where the potential gains leave the current distribution of world income virtually unchanged between the two country groups.' All the more reason for developed countries to seriously consider the opportunity cost of their huge farm subsidies.

During the first reform period, Pakistan has overdone the fulfillment of the UR commitments in freeing agricultural commodities trade. Table-4 shows that the divergence between the average unweighted applied and bound tariff in agriculture has been widest in Pakistan amongst the four major South Asian countries.

${ }^{5}$ According to the World Bank's estimates for 1997, the developing countries, with almost $80 \%$ of the world population, subsisted on less than $20 \%$ of the world's income (See World Bank, 1998). 
Table-3: Welfare Gains from Removing Trade Barriers in the PostUruguay Round World of 2005 (1995 US\$ billions)

\begin{tabular}{lcccccccccc}
\hline Category & \multicolumn{2}{c}{$\begin{array}{c}\text { Agriculture } \\
\text { and food }\end{array}$} & \multicolumn{2}{c}{$\begin{array}{c}\text { Other } \\
\text { primary }\end{array}$} & \multicolumn{2}{c}{$\begin{array}{c}\text { Textiles and } \\
\text { clothing }\end{array}$} & \multicolumn{2}{c}{$\begin{array}{c}\text { Other } \\
\text { manufactures }\end{array}$} & \multicolumn{2}{c}{ Total } \\
& \multicolumn{1}{c}{ Total } & \% & Total & \% & Total & $\%$ & Total & $\%$ & Total & $\%$ \\
\hline $\begin{array}{l}\text { Developed } \\
\text { countries }\end{array}$ & 122.1 & 48.0 & 0.0 & 0.0 & 3.3 & 1.3 & 14.2 & 5.6 & 139.7 & 54.9 \\
$\begin{array}{l}\text { Developing } \\
\text { countries }\end{array}$ & 42.6 & 16.7 & 2.7 & 1.1 & 14.1 & 5.5 & 53.3 & 21.7 & 114.7 & 45.1 \\
\begin{tabular}{l} 
World \\
\hline
\end{tabular} & 164.7 & 64.8 & 2.8 & 1.1 & 17.4 & 6.8 & 69.5 & 27.3 & 254.3 & 100 \\
\hline
\end{tabular}

Source: Anderson et. al. (2001)

Table-4: Uruguay Round Commitments in Agriculture: South Asia

\begin{tabular}{lcc}
\hline Country & \multicolumn{2}{c}{ Average tariff rate (unweighted) } \\
(2000)
\end{tabular}

Source: Athukorala (2000) and WTO (2001).

More importantly, even before the first reform package was announced, Pakistan has been gradually removing input subsidies since the early 1980s, which virtually ceased to exist by 2000 . The input subsidies were to be phased out and replaced by the output support price system under the recommendations of the Pakistan Agricultural Prices Commission (APCom), established in 1981. However, the support price policy scarcely made the national exchequer dole out any funds to the country's farmers, particularly after signing the UR commitments. The scenario presented in Table-5 supports the author's position.

The figures in Table-5 show that the support prices of both rice and cotton in Pakistan have been lower than the domestic market price in the post-UR period. Although the government was not restricted by the UR ruling of the WTO, it has never made any procurement of rice and cotton, except in the first year of implementation, 1994-95, when a very small 
quantity of rice, $.06 \%$ of total production, was procured. On the other hand, the government has been procuring on average a little over $20 \%$ of the total production of wheat annually, apparently going way beyond the limits permitted by the UR commitments. ${ }^{6}$ However, the government's wheat procurement in Pakistan is for food security reasons and not to support the wheat growers since the support price of wheat has been lower than its market price till 1998-99; the former being only marginally higher than the latter in 1999-2000. Such a small divergence does not warrant procurement in widely prevalent and successful support price models. ${ }^{7}$

\section{Table-5: Support Price, Market Price and Procurement of Major Crops (Pakistan: 1994-00)}

\begin{tabular}{|c|c|c|c|c|c|c|}
\hline \multirow[t]{2}{*}{ Category $^{+}$} & \multicolumn{6}{|c|}{ Year } \\
\hline & $1994-95$ & $1995-96$ & 1996-97 & $1997-98$ & $1998-99^{*}$ & $1999-00$ \\
\hline \multicolumn{7}{|l|}{ 1. Wheat } \\
\hline Support price & 160 & 173 & 240 & 240 & - & 300 \\
\hline Market price & 176 & 185 & 273 & 259 & 261 & 297 \\
\hline Procurement (a) ${ }^{\dagger}$ & 3.74 & 3.45 & 2.72 & 3.98 & 4.07 & 8.55 \\
\hline Procurement (b)" & $22 \%$ & $20 \%$ & $16 \%$ & $21 \%$ & $23 \%$ & $41 \%$ \\
\hline \multicolumn{7}{|l|}{ 2. Rice } \\
\hline Support price & 211 & 222 & 255 & 310 & 330 & 350 \\
\hline Market price & 192 & 231 & 296 & 297 & 362 & 358 \\
\hline Procurement (a) & 21 & 0.12 & - & - & - & - \\
\hline Procurement (b) " & $0.6 \%$ & - & - & - & - & - \\
\hline \multicolumn{7}{|l|}{ 3. Cotton } \\
\hline Support price & 423 & 423 & 540 & 540 & - & 825 \\
\hline Market price & 794 & 739 & 840 & 808 & 876 & 580 \\
\hline Procurement (a) & - & - & - & - & - & - \\
\hline Procurement (b) & - & - & - & - & - & - \\
\hline
\end{tabular}

Source: APCom (2001) and Pakistan Economic Survey (2002-03).

\footnotetext{
${ }^{6}$ Exactly 30 WTO members have commitments to reduce their trade distorting domestic support in the amber box as measured by their AMS. Members without these commitments have to keep within $5 \%$ of the value of production level, $10 \%$ in the case of developing countries (for further clarification of this point, see Part II and footnote 15 of this study).

${ }^{7}$ For example, the Common Agricultural Policy (CAP) of the EU has three interrelated components: price support, import control and export subsidies. The EU determines target prices for grains every year after intensive bargaining between the producing and the consuming interests. A target price and an intervention price is derived. The latter is set at 5-7 percent below the target price. When the market price in the Union falls to the intervention price level, procurement begins. In this sense the intervention price of a cereal represents the minimum support price for producers. In addition, for controlling grain imports the EU employs an import tax, variable levy, designed to equalize the import price with a decreed domestic price (see Kreinin, 1995, P. 186-7).
} 
+ All prices are in rupees per $40 \mathrm{~kg}$.

${ }^{+}$Procurement in million tonnes.

${ }^{\Delta}$ Procurement in million tonnes

-Procurement as percentage of total production.

"No support price was announced for 1998-99 wheat crop.

In all fairness, the figures listed in Table-5 show that APCom has been tinkering rather than fine tuning while calculating the support price mark up. The official publications do provide the elaborate goals of the support price, but the information on its mechanism and implementation is very general and extremely vague. Also, empirical evidence shows that there has been a huge transfer of welfare gains from producers to the consumers (Ashfaq et. al. 2001; Niaz 1995). It may therefore be concluded that even during the first reform period, agricultural policies have been penalizing rather than rewarding the farmers in Pakistan.

\section{Part III}

The shortcomings of reform efforts by developing countries such as Pakistan are often escalated in a world of unequal trade partners, as the huge agricultural subsidies received by the developed countries' farmers encourage overproduction and distort trade by making farm goods artificially cheap internationally.

Farm protection is ubiquitous in developed countries. It has a formidable history which dates back to the Corn Laws that had protected British Farmers from imports of foreign grain for 200 years. ${ }^{8}$ After an ugly struggle, the British Parliament eventually voted for reform in 1846. Powerful countries have found a pretext in every age to protect their farmers. In 19th century Europe, the pretext was unfair competition from cheap American and Australian imports. In the 1930s it was farm poverty. After the Second World War it was food security and later on it became preservation of the rural character. 'With advancements in communication technology, the issue of farm support has now become a potent emotional and political force the world over. In the EU and US, the farm lobbies wield influence out of all proportions to the share of the farm sector in these countries' GDP and the labor force.

\footnotetext{
${ }^{8}$ Adam Smith devoted Chapter 5 of Book IV to subsidies, called "bounties" in his time. Although he discussed bounties in the context of foreign trade, the main issues are the same (see Smith, 1776, pp. 398-408).

${ }^{9}$ See, 'A Survey of Agriculture', The Economist, December 12, 1992.
} 
Before exploring the implications of the size and significance of agricultural subsidies of developed countries, it will be helpful to have an overall idea of the players' stakes in the international market for agricultural products. Table- 6 presents the share of leading exporters of agricultural products in the world receipts from agricultural exports between 19802002. The most significant development to be noted is that the US share declined by about $3 \%$ in 10 years to 1990 , and the EU share increased markedly during the same period. This may be explained by Greece, Portugal and Spain, all having a comparative advantage in agriculture, joining the EU, then the European Community. ${ }^{10}$

\section{Table-6: International Trade in Agricultural Products: Leading Exporters (1980-2002)}

\begin{tabular}{lcccc}
\hline \multirow{2}{*}{ Country/Group } & \multicolumn{4}{c}{ World export of agricultural products } \\
& \multicolumn{4}{c}{ (\% share in total export receipts) } \\
\hline EU15 & 32.8 & 42.4 & 39.6 & $\mathbf{2 0 0 2}$ \\
US & 17.0 & 14.3 & 12.9 & 11.8 \\
Canada & 5.0 & 5.4 & 6.3 & 5.6 \\
Brazil & 3.4 & 2.4 & 2.8 & 3.3 \\
China & 1.5 & 2.4 & 3.0 & 3.2 \\
Australia & 3.3 & 2.8 & 3.0 & 2.9 \\
Argentina & 1.9 & 1.8 & 2.2 & 2.2 \\
Thailand & 1.2 & 1.9 & 2.2 & 2.0 \\
Indonesia & 1.6 & 1.0 & 1.4 & 1.5 \\
Malaysia & 2.0 & 1.8 & 1.5 & 1.5 \\
New Zealand & 1.3 & 1.4 & 1.4 & 1.4 \\
Russia & - & - & 1.4 & 1.3 \\
Chile & 0.4 & 0.7 & 1.2 & 1.2 \\
India & 1.0 & 0.8 & 1.2 & 1.1 \\
\hline
\end{tabular}

Source: WTO (2003)

$\diamond$ Russian Federation.

\footnotetext{
${ }^{10}$ This observation provides food for thought for why after 1990 the US became interested in the expansion of NAFTA. Also, on the issue of farm subsidies the two powers, EU and the US, were likely to make or break the UR negotiations. Each insisted that an unsatisfactory deal will be rejected, even if that means no deal at all (see "GATT: The Eleventh Hour" The Economist, December 4, 1993).
} 
Agricultural policies pursued by developed countries cause major distortions which seriously hinder market access for developing countries. Progress made in reducing protection in developed countries has remained unsatisfactory to the extent that the Doha Round, launched in November 2001, was suspended in July 2006, after negotiators failed to reach an accord on agricultural subsidies and market access. The subject continued to lead to dispute and controversy even in the March 2-4, 2007, 'miniministerial' meeting in Kenya. Figures listed in Tables 7-9 provide a backdrop to understanding the Doha Round stalemate.

\section{Table-7: Agricultural Support in OECD Countries}

\begin{tabular}{lcc}
\hline Agricultural Support Estimates & $\mathbf{1 9 8 6 - 8 8}$ & $\mathbf{2 0 0 1 - 0 3}$ \\
\hline Total support (US\$ b) & 303.720 & 324.053 \\
Producer Support & 241.077 & 238.310 \\
General Services Support & 40.946 & 57.849 \\
Fiscal Transfers to Consumers & 21.697 & 27.894 \\
Support per farmer (US\$ thousands) & 10 & 11 \\
Support per hectare (US\$) & 183 & 182 \\
\hline
\end{tabular}

Source: OECD, Agricultural Policies in OECD Countries, 2003.

It is observed that, in nominal terms, the OECD countries together pay more subsidies to their farmers in the post-UR period. More importantly, although the producer support shows an overall decline, rather than decreasing, the support per farmer has increased. This trend, especially when compared with marginally reduced support per hectare, suggests that the progress of developed countries in reducing farm subsidies scarcely goes beyond a cosmetic exercise.

Table-8: Agricultural Support in OECD Countries: Relative Shares

\begin{tabular}{lcc}
\hline Region/Country & \multicolumn{2}{c}{ Percentage Share in Total OECD Support } \\
\cline { 2 - 3 } & $\mathbf{1 9 8 6 - 8 8}$ & 2001-03 \\
\hline EU & 37 & 36 \\
United States & 24 & 29 \\
Japan & 20 & 17 \\
Korea & 5 & 6 \\
Others & 14 & 12 \\
Total & 100 & 100 \\
\hline
\end{tabular}

Source: OECD, Agricultural Policies in OECD Countries, 2003. 
Figures listed in Table- 8 and Table-9 provide a closer insight into the implications of OECD farm subsidies for the reform efforts of developing countries.

Table-9: Size of Agricultural Support in Major Developed Countries: 2001-03

\begin{tabular}{lcccc}
\hline Region/country & \multicolumn{4}{c}{ Support Estimates } \\
\cline { 2 - 5 } & $\begin{array}{c}\text { Total } \\
\text { support }\end{array}$ & $\begin{array}{c}\text { Producer } \\
\text { support }\end{array}$ & \multicolumn{2}{c}{ Averages } \\
\cline { 2 - 5 } & \multicolumn{2}{c}{ US\$ b } & Per farmer & Per bectare \\
\hline OECD & 324.053 & 238.310 & 11 & 182 \\
EU & 114.720 & 102.708 & 15 & 670 \\
United States & 95.128 & 44.239 & 19 & 112 \\
Japan & 56.489 & 5.359 & 23 & 9828 \\
Others & 57.716 & 86.004 & - & - \\
\hline
\end{tabular}

Source: OECD, Agricultural Policies in OECD Countries, 2004.

Table- 8 provides information on the relative share of agricultural support provided by member countries of the OECD. The figures show that the EU's share of the agricultural dole out is largest, followed by the US and Japan. Moreover, per farmer support, listed in Table-9, of the EU, US and Japan happens to be much above the OECD average. Japan appears to be contributing most in this scenario, followed by the US. However, the relative significance of Japanese and American farm subsidies needs to be considered taking account of the much larger relative size of the farm sector of the latter with a comparative advantage in agriculture in addition to technological competitive advantage, particularly when compared with the developing countries. Japanese farm subsidies, though contributing to global inefficiency, do not hurt farmers elsewhere as the country is not listed in the league of leading agricultural exporters (See Table-6). ${ }^{11}$

From the viewpoint of global efficiency, the scenario presented in Tables 7-9 is bad enough, but the worst part, particularly in the context of the argument of this study, is that rather than falling, as was required

\footnotetext{
${ }^{11}$ Most of the Japanese farm subsidies go to the rice growers for ensuring selfsufficiency in rice production. Rice is the staple food grain in Japan. For Japan, rice is a near-sacred product, deeply embedded in history, culture, economics, politics, and symbolism. For the Japanese the rice is the Christmas tree and rice producing land is reverently called our holy land (see Blaker, 1999).
} 
under the UR obligations, the developed countries' farm subsidies have been increasing. The available estimates show that in 2001, the US had increased its subsidy to $21 \%$ of the gross farm receipts, while the EU was contributing $35 \%$ of gross receipts of its farmers (OECD 2002)..$^{12}$ Finally, in May 2002, the US passed legislation to further increase the amount the government pays to farmers. The new Farm Act provides an additional $\$ 83$ billion in subsidies above the existing program during the next decade. ${ }^{13}$

These developments are in gross violation of the AoA which established commitments at the UR to limit and reduce baseline domestic support, as measured by the Aggregate Measure of Support (AMS). This was the most innovative element of the AoA because trade distortions arising from domestic support policies were for the first time formally recognized (Schluep and Gorter 2001). A key aspect of the reductions commitments in the domestic support was the distinction between domestic policies that distort trade and those that do not. This makes it possible to focus on trade distorting policies, negotiate reductions in their magnitude and provide an incentive for governments to re-instrument their domestic policies towards non-distorting measures (Schmitz and Vercammen 1995). However, most countries could circumvent their AMS commitments because of an extremely high base period upon which commitments were made and because of the sector-wide nature of the support commitments (OECD 2000). Hence, the AMS has been the least binding element of the AoA commitments for most countries. Moreover, the establishment of the blue box and green box which were both exempted from reduction requirements further weakened the domestic support element of the Agreement. ${ }^{14}$ Total support provided by amber policies on production was measured by the AMS, which countries agreed to reduce by 20 percent in the 1995-2000 implementation period (OECD 1999).

\footnotetext{
${ }^{12}$ Also see "The Doha squabble," The Economist, March $27^{\text {th }} 2003$.

${ }^{13}$ See "Why U.S. Farm Subsidies Are Bad for the World" Philadelphia Inquirer, May 6, 2002.

${ }^{14}$ In WTO terminology, "boxes" which are given the colors of traffic lights in general identify subsidies: green (permitted), amber (slow down - i.e. be reduced), and red (forbidden). The AoA has no red box, although domestic support exceeding the reduction commitment levels in the amber box is prohibited; and there is a blue box for subsidies that are tied to programs that limit production. Amber box policies include transfers from consumers such as administered price supports but also taxpayer-funded subsidies for both inputs and output. The accounting method is either government expenditures or price gaps using the "equivalent method of support" (EMS) measure. Green box policies include decoupled payments (that purportedly do not affect production decisions) and policies to correct for market failures such as environmental programs, research, food aid, and crop insurance and income safety net programs. This class of policies is generally taxpayer funded that does not involve transfers from consumers.
} 
As mentioned above, the AoA sought to define, quantify and reduce trade distorting policies. It included three areas, namely, import access, export subsidies and domestic support. However, the figures listed in Table 7-9 suggest that the AoA cannot be rated as a success because, despite support reduction commitments, the absolute size of the developed countries' subsidies has in fact increased over the implementation period. ${ }^{15}$

\section{Part IV}

The Cancún Ministerial Meeting in September 2003 was the second disappointment for the WTO in four years. Before the Doha Round was launched in November 2001, its meeting in Seattle in December 1999 broke down, largely because of the undue pressure exerted by the developed countries on extraneous issues. The trade round stagnated for 22 months between the meetings in Doha and Cancún. After a long stalemate, and at the behest of many developing countries, the US and the EU drew up a framework in August 2003 for freeing farm trade. Though it involved some reform, the plan was much less ambitious than the Doha Round had implied. Export subsidies, for example, were not to be eliminated after all. ${ }^{16}$ Angered by this lack of ambition, a new block of developing countries emerged just before the Cancún meeting to denounce the EU/US framework as far too timid. Led by Brazil, China and India, this so-called G22 became a powerful voice at the Cancún Ministerial Meeting in September 2003..$^{17}$

Given the analysis in Part III, developing countries were understandably dissatisfied at Cancún with the commitment of developed countries to agricultural reforms. Many demanded concessions on agriculture from the US and the EU before talks could move forward, and consequently refused to negotiate. Although it spanned diverse interests India, for instance, is terrified of lowering tariffs on farm goods, while Brazil, a huge and competitive exporter, wants free trade as fast as possible-the G22 stood together and managed to effectively block the consensus required to do anything in the W'TO. The Group's initiative ought to be viewed in the light that farm trade is not some peripheral

\footnotetext{
15 The European Union, Japan and the United States account for over 85 percent of total domestic support under the AMS [see, OECD 2002].

${ }^{16}$ For a better insight into the plan, see "More fudge than breakthrough," The Economist, June $26^{\text {th }} 2003$.

17 The Group included Argentina, Bolivia, Brazil, Chile, China, Columbia, Costa Rica, Cuba, Ecuador, Egypt, Guatemala, India, Indonesia, Mexico, Nigeria, Pakistan, Paraguay, Peru, Philippines, South Africa, Thailand, Venezuela (see "The WTO under fire," The Economist September $18^{\text {th }}, 2003$ ).
} 
issue. It is central to the whole round. Being a development round, Doha Round was launched with much fanfare. Many developing countries felt they had a raw deal from the UR. They were dragged reluctantly into yet another set of trade negotiations largely by the promise of freer trade in farm goods.

A group of four West African countries-Benin, Burkina Faso, Chad and Mali-managed to have cotton included as an explicit item on the Cancún agenda. Their grievances were simple and justified. West African cotton farmers are being crushed by the $\$ 3$ billion-plus a year subsidy that US squanders on its 25,000 cotton farmers, helping to make it the world's biggest exporter, depressing prices and wrecking the global market. ${ }^{18}$ With low labor costs and small manageable plots, farmers in West and Central Africa are among the lowest-cost producers of cotton in the world. The International Cotton Advisory Committee puts the cost of producing a pound of cotton in Burkina Faso at 21 US cents compared to 73 cents in the US itself. However, state subsidies guarantee a minimum price to US farmers, regardless of what happens to world prices. US farmers also receive additional payments to augment their incomes to a target price level. As a result, they continued to expand cotton production, by $42 \%$ between 1998 and 2001, oblivious to almost five years of depressed world prices. In 2002, partly due to the continuous flooding of the market by US cotton, world cotton prices fell to 42 cents per pound, far below the long-term average of 72 cents. During the 2001/02 season, the US government paid more to its cotton farmers in support than the value of the harvested crop, $\$ 3.9$ billion in subsidies for a crop valued at $\$ 3$ billion. These subsidies were responsible for 65 per cent of the $\$ 300$ million loss in potential revenue in all of Sub-Saharan Africa in 2002. Benin, Burkina Faso, Mali, Cameroon and Côte d'Ivoire were hit hardest. According to another estimate, the US spends $\$ 10.7$ million per day subsidizing its cotton farmers, which is three times the total aid given to Sub-Saharan Africa (UNDP 2003). As mentioned earlier, in May 2002, the US passed legislation to further increase the amount that the government pays farmers. The new Farm Act provides an additional $\$ 83$ billion in farm expenditure, above the $\$ 100$ billion spent on existing programs. Cotton growers, mainly comprising corporate agricultural companies, are expected to receive an additional $\$ 2.5$ billion over a decade. ${ }^{19}$ This has inflamed an

\footnotetext{
${ }^{18}$ See "The WTO under fire," The Economist, September 18, 2003.

${ }^{19}$ See http://www.business-standard.com, August 7, 2003.
} 
already raging controversy around agricultural subsidies and has stirred anger in developing countries. ${ }^{20}$

The EU is no less harmful. Its farm reforms may be radical by the organization's undemanding standards but will not be enough to satisfy the rest of the world. For example, even though its production costs are more than double to that of Asian and Latin American countries having a natural comparative advantage, the EU is now the second largest sugar exporter from being a net importer 30 years ago. The EU spends about $\$ 3.3$ billion annually in supports on sugar exports, and in mid-2002 was paying its producers a guaranteed price three times that was being offered on the world market. Due to EU subsidies, prices on the world sugar market have fallen by $17 \% .^{21}$ However, the sugar subsidy is only the tip of the iceberg. The annual dairy subsidy in the EU is $\$ 913$ per cow, which is almost double the per capita income of Sub-Saharan Africa at $\$ 490$ and 114 times the annual per capita aid given by the EU to this region. It gets worse when it comes to Japan, where each cow gets $\$ 2,700$ to chew each year, a figure that is more than five times the per capita income of sub-Saharan Africa (UNDP 2003).

\section{Conclusion}

Being a developing open economy, the success of Pakistan's agricultural reform efforts is conditional on the international market situation. Agriculture stands out as the most distorted part of the world economy. The most damaging feature of the Common Agricultural Policy (CAP) of the EU and of the US Farm Support Program is that agricultural subsidies are tied to production, with surpluses dumped on world markets via the payment of export subsidies. The sufferers are mainly developing countries, many of whose economies depend heavily on agriculture. For most developing countries, phasing out all farm-export subsidies is the biggest single objective of the Doha round.

\footnotetext{
${ }^{20}$ Indeed, Brazil has lodged a legal challenge against the US at the WTO, charging that it is in breach of the "peace clause" of the Organization's AoA. The clause, ironically introduced at the insistence of the US and EU during the UR trade negotiations, protects a country from challenge to its subsidy regimes as long as it does not raise them beyond levels set in 1992. No African or Asian nation has yet filed a legal suit at the WTO against the developed countries' farm subsidies. Many are cash-strapped, dependent on aid and debt relief from the very countries they would be challenging. Many are also wary of the potential for retaliatory action.

${ }^{21}$ See http://www.business-standard.com, August 7, 2003.
} 
Ironically, the rules prohibiting subsidies were supported and organized within the WTO by the same countries that are violating the UR ruling on farm subsidies. Much of the blame lies with the AoA itself. In theory, the Agreement requires all member countries to reduce subsidies that hinder trade, but numerous loopholes and rules, the 'peace clause' for example, are weighted in favor of the more dominant members of the W'TO, allowing them to avoid reducing agricultural subsidies and continue raising them in some cases.

Lower tariff barriers and a big cut in the developed countries subsidies have strategic significance for the developing world as a whole. An estimated $96 \%$ of the world's farmers live in developing countries, with some 2.5 billion people depending on agriculture for a livelihood. Over the years, unfavorable trade terms have been a major factor in the erosion of the market share of developing nations. According to the WTO, the share of the South in world agricultural exports fell from $40 \%$ in 1961 to $35 \%$ in 2002 . $^{22}$ The huge subsidies of developed countries depress farm prices and place the farmers of developing countries at a big disadvantage. US taxpayers, along with their European counterparts, bear a direct responsibility for poverty in the world.

Finally, can any of the failures outlined in this study be effectively addressed and the Doha Round revived? Presently, there is little room for optimism in that the North lacks a holistic and farsighted approach to the interdependence and complimentarity of the world economy, while the South appears to be as divided and disorganized as ever. The G22, for instance, left Cancún determined to stick together and fight another day. Since after, quite a few member countries of the G22 alliance have been negotiating free trade agreements with the US. Their commitment to the free trade of farm goods and their interests in pursuing the strong market access commitments, requiring free trade agreements with the US, do not appear to be in harmony with each other. This leads to the final concluding remarks that in the previous rounds of the GATT and WTO, the negotiations by the developing countries have amply exhibited the unfortunate lack of leadership. Cancún provided some short-lived hope, as the subsequent developments suggest that it too has failed to pass the time test.

\footnotetext{
${ }^{22}$ http://www.business-standard.com, August 7, 2003.
} 


\section{References}

APCom, 2001, Pakistan Journal of Agricultural Economics, Vo1. 4, No. 1, January 2001, Pakistan Agricultural Prices Commission, Islamabad.

Anderson K., C. McRae and D. Wilson (eds.), 2001, The Economics of Quarantine and the SPS Agreement, Adelaide: Centre for International Economic Studies and Canberra: Biosecurity Australia.

Ashfaq M., G. Griffith and K. Parton, 2001, "Welfare Effects of Government Interventions in the Wheat Economy of Pakistan", Pakistan Journal of Agricultural Economics, Vo1. 4, No. 1, pp.25-33.

Athukorala P., 2000, “Agriculture Trade Agenda in the WTO Negotiations: Interests and Policy Options for South Asia”, Journal of Asian Economics, 11(2), pp. 169-93.

Balassa B., 1965, "Trade Liberalization and 'Revealed' Comparative Advantage”, Manchester School of Economic and Social Studies, 33(2), pp. 99-124.

Blaker M., 1999, "Japan Negotiates With the United States on Rice: "No, No, A Thousand Times, No!”, in Berton P., H. Kimura and I. W. ZartMan (ed.), International Negotiation, Macmillan, Hampshire.

FAO, 2000, Agriculture, Trade and Food Security, Vo1. 1 and 2, Rome, Food and Agricultural Organization, Rome, Italy.

Government of Pakistan, 2003, Pakistan Economic Survey, 2002-03, Ministry of Finance, Economic Affairs Division, Islamabad

Khan N. Z., 1998, "Textiles Sector of Pakistan: The Challenge Beyond 2004”, The Pakistan Development Review, 37:4, Part II, Winter, pp. 595-619.

Kreinin M. E., 1995, International Economics: A Policy Approach, The Dryden Press, New York.

Niaz S. N., 1995, Pricing of Farm Produce in Pakistan: Objectives, Practices and Experiences, Print Associates International, Islamabad. 
OECD, 1999, “A Matrix Approach to Evaluating Policy: Preliminary Findings from PEM Pilot Studies of Crop Policy in the EU, the US, Canada and Mexico", COM/AGR/CA/RD/TC(99)117/Final. Organization for Economic Cooperation and Development, Paris, France.

OECD, 2000, “A Preliminary Report of Domestic Support Aspects of Uruguay Round Implementation”, COM/AGR/APM/TD/WP(2000) 9 February, Organization for Economic Cooperation and Development, Paris, France.

OECD, 2002. "Agricultural Policies in OECD Countries: Monitoring and Evaluation 2002”, Organization for Economic Cooperation and Development, Paris, France.

Schluep I. and H. de Gorter, 2001, "The Definition of Export Subsidies and the Agreement on Agriculture", in G. Peters (ed.), Tomorrow's Agriculture: Incentives, Institutions, Infrastructure and Innovations”, Oxford University Press.

Schmitz A. and J. Vercammen, 1995, "Efficiency of Farm Programs and their Trade-Distorting Effect" in G. Rausser (ed.), GATT Negotiations and the Political Economy of Policy Reform, pp. 35-36. Oxford University Press.

Smith A., 1776, An Inquiry into the Nature and Causes of the Wealth of Nations, by J. R. McCulloch, Published by the Grand Colosseum Warehouse Co., Glasgow, U.K.

UNDP, 2003, Human Development Report 2003, New York, Oxford University Press.

World Bank, 1998, World Development Report, 1998/99: Knowledge for Development, New York: Oxford University Press.

World Bank, 2001a, World Development Indicators 2001, Washington D.C., The World Bank.

World Bank, 2001b, Global Economic Prospects and the Developing Countries 2002: Making Trade Work for the World Poor, Washington D.C., The World Bank. 
WTO, 2001, "Market Access: Unfinished Business: Post-Uruguay Round Inventory and Issues”, Special Study No. 6, Geneva: World Trade Organization.

WTO, 2003, International Trade Statistics 2003, Geneva: World Trade Organization. 